\title{
EXPERIMENTAL STUDY OF THE WATER PERMEABILITY AND SCOURING RESISTANCE OF CRUSHED-ROCK HIGH-POLYMER COMPOSITES
}

\author{
EKSPERIMENTALNA ŠTUDIJA VODNE PREPUSTNOSTI IN \\ IZPIRALNE ODPORNOSTI VISOKO POLIMERNIH KOMPOZITOV \\ Z DODATKOM ZDROBLJENEGA KAMENJA
}

\author{
Jian Zhang*, Yunfan Gu \\ Nanjing Vocational Institute of Transport Technology, Nanjing 211188, China \\ Prejem rokopisa - received: 2019-05-06; sprejem za objavo - accepted for publication: 2019-06-27
}

doi:10.17222/mit.2019.138

\begin{abstract}
In this paper, a new type of crushed-rock high-polymer composite material is proposed. This material not only retains the porous characteristics of crushed rock but also enhances the integrity of crushed rock and has excellent engineering characteristics in terms of water permeability and scouring resistance. Through the developed indoor scouring test system and pavement permeameter, the scouring resistance and water permeability of the composites were studied, and the effects of the material mixture ratio (high polymer: crushed rock), the particle size of the crushed rock and the flow rate were analysed. The results showed that the crushed-rock high-polymer composites had large pores and good water permeability. The water permeability of the composites increased with the increase in the particle size of the crushed rock and decreased with the increase in the material mixture ratio, but the decrease was insignificant. The high polymer in the composite material made the crushed-rock particles cemented to form a whole from point stability to block stability, which could resist the scouring of high-speed flow and had excellent scouring resistance. With an increase in the particle size of the crushed rock and the material mixture ratio, no erosion occurred in the composites, thereby indicating that increasing the particle size of the crushed rock and the material mixture ratio would improve the scouring resistance of the composites.

Keywords: crushed rock, high polymer, water permeability, scouring resistance
\end{abstract}

V prispevku avtorji predlagajo nov tip polimernega kompozita z izbrano vsebnostjo zdrobljenega kamenja kot ojačitveno fazo. Ta material ne ohranja samo poroznosti zdrobljenega kamenja, temveč tudi izboljša njegovo integriteto in ima odlične inženirske lastnosti, kot sta prepustnost za vodo in odpornost proti izpiranju. Avtorji so razvili lastni sistem za testiranje odpornosti proti izpiranju in parameter obrabe pločnika (ali druge protidrsne prevleke na površini ceste, npr. grbine, klančine) $\mathrm{s}$ katerim so testirali odpornost proti izpiranju in prepustnost za vodo izdelanih kompozitov. Analizirali so vpliv pretoka vode na izbrane materialne mešanice $\mathrm{v}$ kompozitu oziroma na razmerje med deležem visokega polimera (poliuretana, ki se ne peni med mešanjem) in zdrobljenega kamenja ter njegovo velikostjo delcev. Rezultati preiskav so pokazali, da ima izdelani polimerni kompozit, ki vsebuje izbrano vsebnost in velikost zdrobljenega kamenja velike pore in dobro prepustnost za vodo. Vodna prepustnost polimernega kompozita naraste s povečanjem velikosti zdrobljenega kamenja in se zmanjša s povečanjem deleža polimera v mešanici. Vendar je ta vpliv nepomemben. Visoki polimer v kompozitu je povzročil utrditev kompozita v kompaktno in stabilno celoto z odlično odpornostjo proti izpiranju tudi pri preizkusih z visokimi hitrostmi pretoka vode. Tudi pri povečanju velikosti zdrobljenega kamenja in povečanju njegovega deleža ni prišlo do erozije kompozita, kar kaže na to, da bi le-to lahko izboljšalo njegovo odpornost proti izpiranju.

Ključne besede: zdrobljeno kamenje, visoki polimer (poliuretan, ki se ne peni), prepustnost za vodo, odpornost proti izpiranju

\section{INTRODUCTION}

A protective covering is one of the important facilities for slope protection that is the main application field of various new technologies, materials and processes in slope engineering. Crushed-rock high-polymer composite material refers to the composite material formed by mixing ordinary engineering crushed rock with a high polymer in a certain proportion, and composite water permeability protective covering with crushed rock and high polymer can be formed by laying this composite material directly on the structural surface..$^{1-3}$ In contrast to general impermeable protective materials, such as concrete, the high polymer content in crushed-rock

*Corresponding author's e-mail:

18626439990@163.com (Jian Zhang) high-polymer composites is low, and the porous properties of crushed-rock materials are retained. Thus, the composite protective covering of the crushed-rock high-polymer is a type of permeable protective covering. Meanwhile, crushed-rock particles are bonded together by the polymer, which enhances the aggregate material integrity. Therefore, crushed-rock high-polymer composite material also exhibits a high scouring and erosion resistance, and the resulting protective covering is a scouring and erosion resistance covering.., 5

Scholars locally and internationally have studied the critical velocity and shear force of the erosion resistance of reinforced turf. Before the emergence of the geotechnical reinforced turf, vegetation revetment is completely excluded from consideration when the flow velocity is $>2.1 \mathrm{~m} / \mathrm{s}$ or the shear force is $>77 \mathrm{~Pa}^{6-8}$ The 
emergence of geotechnical reinforced turf has considerably improved the anti-erosion ability of the vegetation slope protection, thereby making the vegetation ecological slope protection fully applicable to the defence engineering under high flow rate and shear force..$^{9,10}$ R. J. Nelson ${ }^{11}$ conducted field tests on reinforced turf spill-over. The damage index of the reinforced turf was $12.7 \mathrm{~mm}$ ( $0.5 \mathrm{inch})$ erosion. According to the index, the tolerant sheer force of the reinforced turf is $900 \mathrm{~Pa}$. Y. Li et al. ${ }^{12}$ studied the effect of the aging time of geogrids on the erosion resistance of reinforced turf. Y. Pan et al. ${ }^{13,14}$ and L. Li et al. ${ }^{15}$ studied the geotechnical reinforced turf embankment under the combined action of wave and overtopping by carrying out prototype tests in the laboratory. The hydraulic properties and scouring resistance of the high-performance reinforced turf were preliminarily discussed, and the concept of the upper erosion limit of reinforced turf was introduced. The damage mechanism of the reinforced turf was summarised as the tearing effect of continuous current scouring on a geotechnical mat. H. Oumeraci et al. ${ }^{16}$ studied the waveaction characteristics of Basf crushed-rock polyurethane revetment. The study found that the void ratio of the material effectively slowed down the wave velocity on the bank slope surface. Delft University of Technology in the Netherlands also conducted model tests on the stability of Elastocoast breakwater under wave action. The results showed that the open pore structure reduced the force acting on the protective covering by $20-58 \% .^{17,18}$

As a protective material, crushed-rock high-polymer composites need to meet certain water-permeability and scouring-resistance requirements. However, the amount of research in this area is limited. Therefore, the water permeability and scouring resistance of crushed-rock high-polymer composites were studied to provide theoretical and technical support for composite applications.

\section{EXPERIMENTAL PART}

\subsection{Test materials}

In combination with the practical application of the project, limestone-based crushed rock, which mainly included crushed rocks $\mathrm{I}^{\#}$ and II $^{\#}$ with the particle sizes of $\leq 20 \mathrm{~mm}$ and $\leq 40 \mathrm{~mm}$, respectively, was used in the test. The particle size distribution of the two types of crushed rocks was determined by the screening test, as shown in Figure 1. The test results showed that approximately $85 \%$ of the crushed-rock $\mathrm{I}^{\#}$ particles were concentrated at $5-10 \mathrm{~mm}$, and the rest of the particles were essentially distributed at $2-5 \mathrm{~mm}$. Approximately $50 \%$ and $47 \%$ of the crushed rock II $^{\#}$ particles were concentrated at 20-40 $\mathrm{mm}$ and $10-20 \mathrm{~mm}$, respectively. Meanwhile, the particles at $5-10 \mathrm{~mm}$ were only approximately $3 \%$. To analyse the effect of crushed-rock particles on crushed-rock high-polymer properties, crushed rocks $\mathrm{I}^{\#}$ and $\mathrm{II}^{\#}$ were used as raw materials to
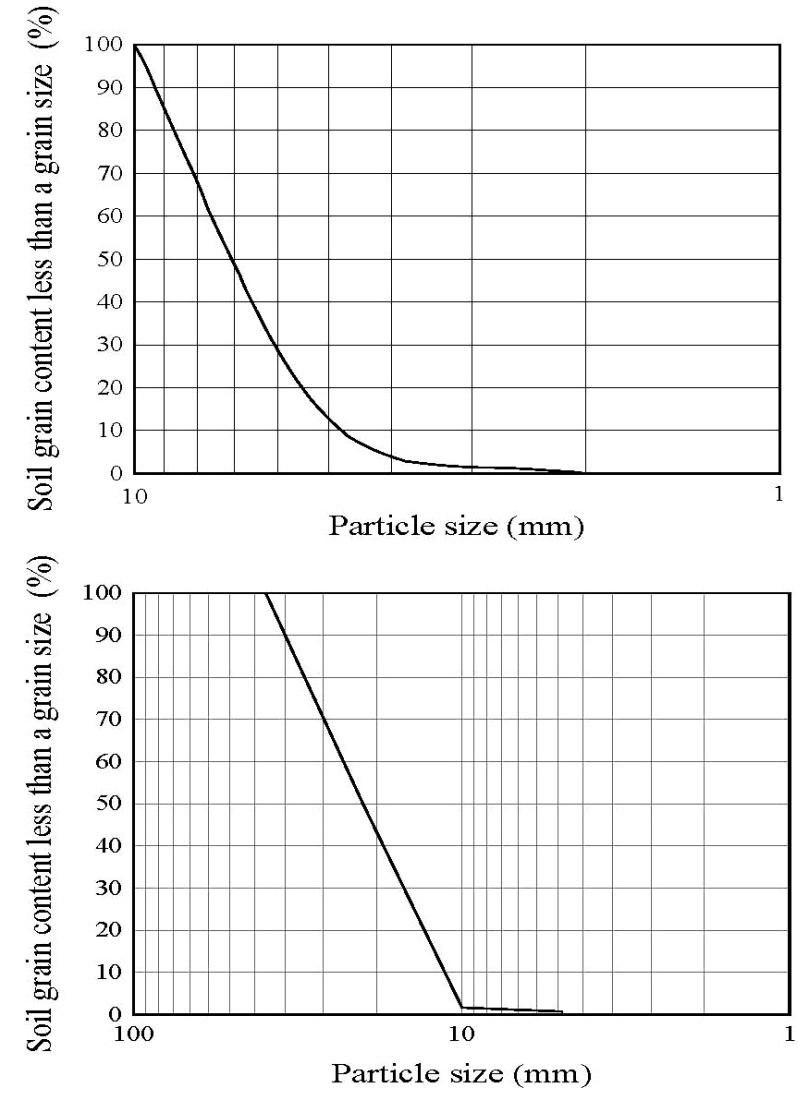

Figure 1: Particle-size-distribution curve: a) crushed rock $\mathrm{I}^{\#}$, b) crushed rock II $^{\#}$

conduct a screening test to obtain crushed rocks with particle sizes of $20-40 \mathrm{~mm}, 10-15 \mathrm{~mm}, 15-20 \mathrm{~mm}$ and 5-10 $\mathrm{mm}$ for the subsequent test.

\subsection{Sample preparation}

Non-foaming polyurethane was chosen as the polymer in this experiment. The high polymer has a strong viscosity. Therefore, in the stirring process of the crushed-rock high-polymer, when the high polymer was wrapped around the crushed-rock particle surface, a certain viscosity was observed between the particles
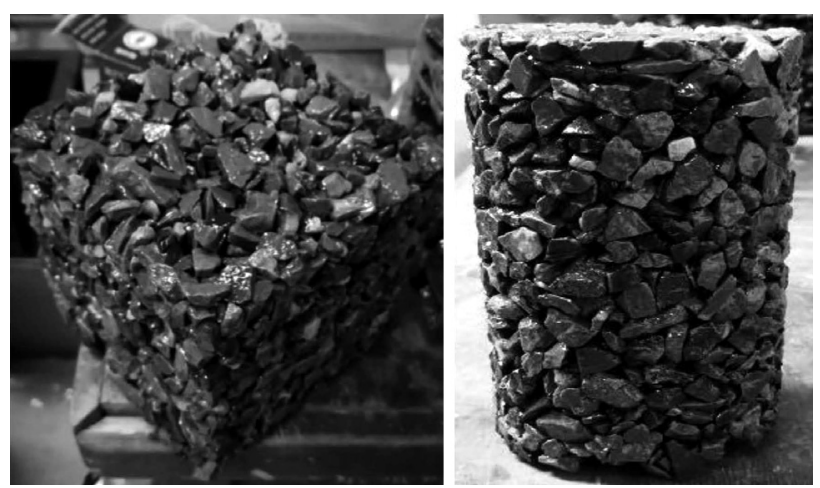

Figure 2: Permeability test sample and indoor scouring test sample: a) permeability test sample, b) indoor scouring test sample 


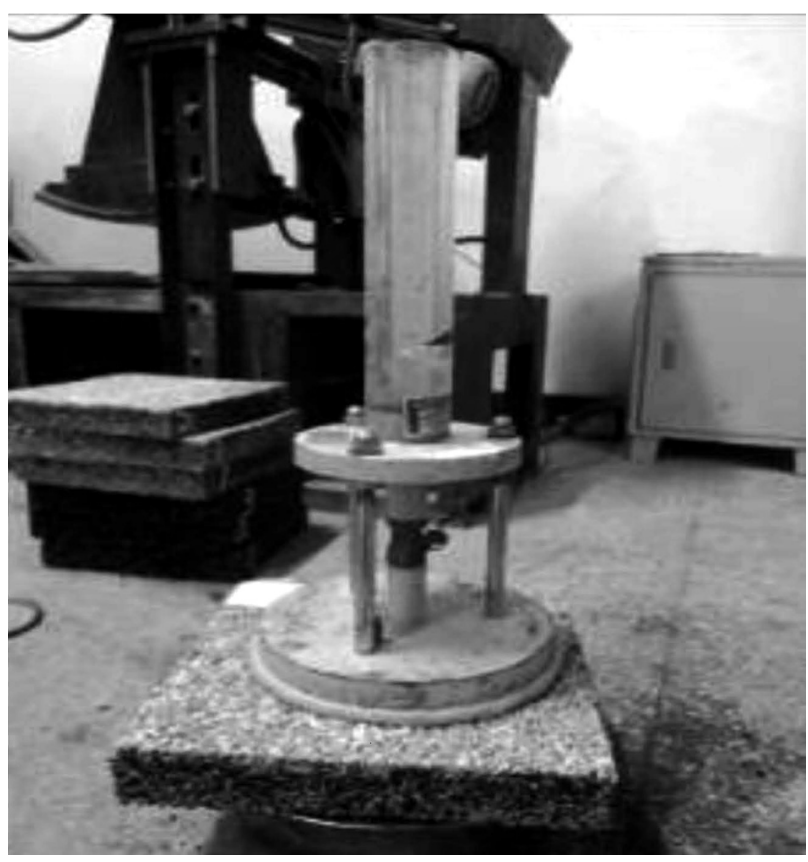

Figure 3: Pavement permeameter

when they were embedded with one other. Therefore, when the mixture was poured into the trial mould, it could not be compacted and formed only by self-weight. If no measures were taken for treatment, then numerous holes in the shaped specimen would be observed which would result in a large defect in the composite itself. Therefore, the crushed-rock high-polymer composites must be compacted by external forces, such as pressure and tamping. The permeability test sample was a cube of $300 \mathrm{~mm} \times 300 \mathrm{~mm} \times 50 \mathrm{~mm}$, and the indoor scouring test sample was a cylinder with a diameter of $100 \mathrm{~mm}$ and a height of $200 \mathrm{~mm}$. The permeability test sample and indoor scouring test sample are shown in Figure 2.

\subsection{Permeability test}

The permeability coefficient is an important index for crushed-rock high-polymer composite material as a permeable protective material. In this study, the permeability coefficient was measured using a pavement permeameter, as shown in Figure 3. The permeability coefficient was calculated according to the following Equation (1):

$$
P_{\text {er }}=\frac{V_{2}-V_{1}}{t}
$$

where $P_{\mathrm{er}}$ is the permeability coefficient, $V_{1}$ is the water volume in the first reading, which is generally $100 \mathrm{~mL}$, $V_{2}$ is the water volume in the second reading, which is generally $500 \mathrm{ml}$, and $t$ is the time interval of the water surface descending from $V_{1}$ to $V_{2}$.

\subsection{Research and development of indoor scouring test device}

To study the scouring resistance of composite materials, we developed an indoor scouring test system, as shown in Figure 4 and Figure 5. The experimental system mainly included water pump, inlet pipe, flow valve, inlet valve, outlet pipe, piezometer tube, pushing system, pressure-regulating valve and secondary sedimentation tank. The water inlet of the inlet pipe was connected with the pump, the water outlet of the inlet pipe was connected with the inlet of the rectangular tube, the water outlet of the rectangular tube was connected with the water inlet of the outlet pipe, and the water outlet of the outlet pipe was connected with the secondary sedimentation tank. The flow valve was located at the inlet end of the inlet pipe, and the inlet valve was

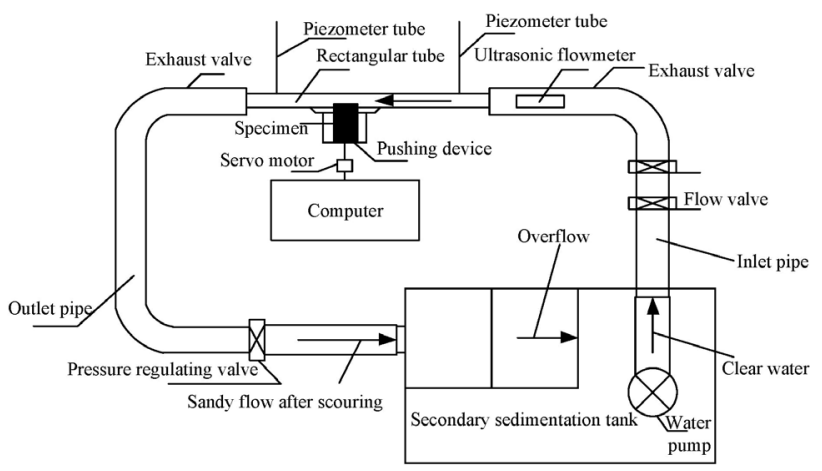

Figure 4: Scheme of indoor scouring test device

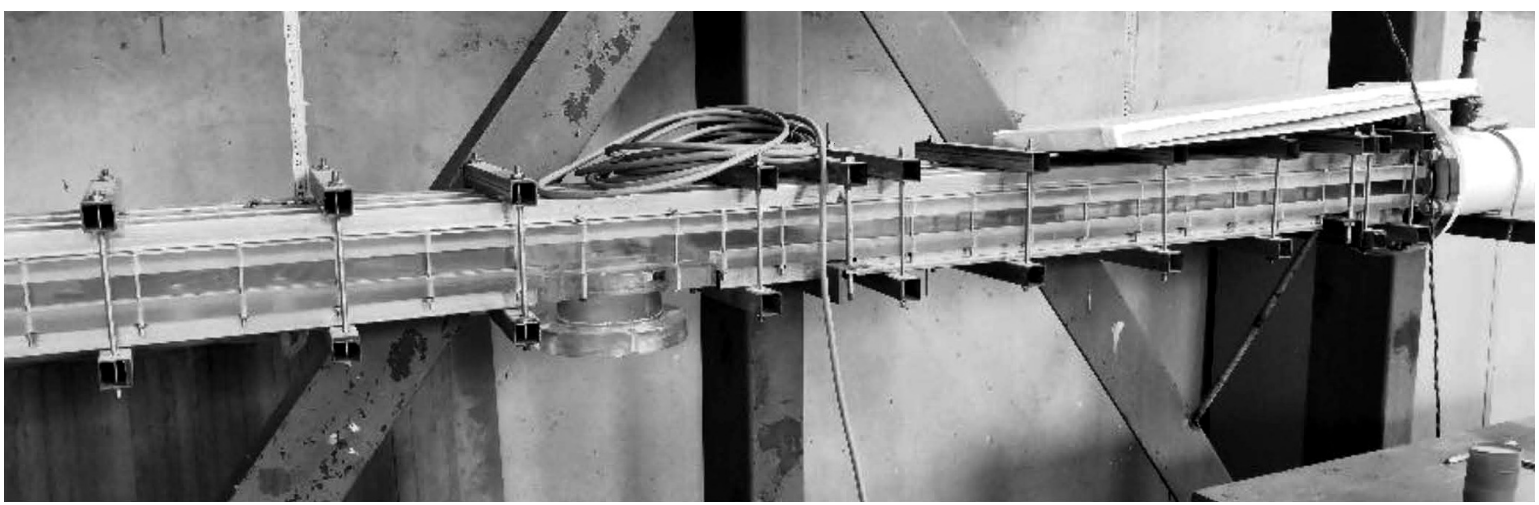

Figure 5: Photograph of indoor scouring test device 
located on the inlet pipe and at the downstream side of the flow valve. The pushing system was connected with the bottom of the rectangular tube, the two piezometer tubes were arranged on the rectangular tube and on both sides of the pushing system, and the pressure regulating valve was located at the outlet end of the outlet pipe. The pushing system included a computer, servo motor and pushing device.

The main working principles of the scouring experiment system are as follows:

1) Adjusting the flow rate and water head showed that when the sample was scoured, the difference in the water head measured through the upstream and downstream piezometer tubes was $\Delta Z$. Thus, the relationship between the pressure difference and the water-head difference is shown as follows:

$$
\begin{gathered}
P_{1}-P_{2}=\gamma \Delta Z \\
\gamma=\rho Z
\end{gathered}
$$

where $P_{1}$ and $P_{2}$ are the pressure values at the section where the upstream and downstream piezometer tubes are located, $\gamma$ is the volume weight of water, $\rho$ is the density of water, and $g$ is the acceleration due to gravity.

2) The relationship between the hydraulic gradient and the water-head difference is shown as follows:

$$
J=\frac{\Delta Z}{l}
$$

where $J$ is the hydraulic gradient, and $l$ is the spacing of piezometer tubes on both sides.

3) The relationship between the incipient shear stress and the pressure difference is shown as follows:

$$
\tau=\frac{P-P_{2}}{l} R
$$

where $\tau$ is the incipient shear stress, $l$ is the spacing between the piezometer tubes on both sides, and $R$ is the hydraulic radius.

4) The relationship between the incipient shear stress and the friction velocity is shown as follows:

$$
\tau=\rho \cdot U_{*}^{2}
$$

where $U_{*}$ is the friction velocity.

According to the steps 1)-4) mentioned above, the starting frictional velocity of the soil sample required for the test can be obtained as follows: $U_{*}=\sqrt{g R J}$.

5) Before the test, the sample mass is $m$ by using the test soil sample, and the sample volume is $V$ by calculating the sample volume, and then the deposition density of the undisturbed soil is as follows:

$$
\rho_{\mathrm{s}}=\frac{m}{V}
$$

where $\rho_{\mathrm{s}}$ is the deposition density.

6) In the test, according to the scouring height $\Delta h$ and scouring time $\Delta t$, the relationship between scouring rate and scouring height per unit time is shown as follows:

$$
q_{w}=\rho_{\mathrm{s}} \frac{\Delta h}{\Delta t}
$$

where $q_{\mathrm{w}}$ is the scouring rate of the undisturbed soil.

The scouring rate of the soil sample required for the test can be obtained from Equation (8).

With this scouring test device, a high-speed water flow can be generated to scour the sample. At the beginning of the test, water was slowly added from the outside of the system to fill the whole rectangular tube through the inlet valve to prevent the water pump from adding too much water and disturbing the sample. An ultrasonic flowmeter was used to determine the velocity of the water flow, so as to improve the accuracy of the test data and the efficiency of the test.

\section{RESULTS AND DISCUSSION}

\subsection{Influence of material mixture ratio on the void ratio of composites}

The permeability of crushed-rock high-polymer composites depends on the effective void ratio, including the interconnected and semi-closed pores, i.e., the measured pore in this experiment. The void ratio of the composites was measured under different particle sizes and material mixture ratios.

In this study, the volumetric method was used to measure the porosity. Only the interconnected pores and semi-closed pores in the porous material of crushedstone high-polymer were measured. The volumetric method used an electronic balance to weigh the weight of the specimen after drying and in water, respectively. The difference between the two is the buoyancy of the specimen, due to the pore filling with water. Assuming that the specimen has no pores, the formula for calculating the porosity can be obtained by subtracting the actual buoyancy from the theoretical buoyancy, as shown in Equation (9). This method is simple and fast, and can quickly determine the porosity of a large pore structure.

$$
e=1-\frac{m_{2}-m_{1}}{V \rho_{\mathrm{w}}}
$$

where $e$ is void ratio, $m_{1}$ is mass of specimens in the water, $m_{2}$ is mass of dried specimens, $V$ is volume of the specimen, $\rho_{\mathrm{w}}$ is density of water under the test condition.

The experimental results are shown in Figure 6.

Figure 6 shows that the void ratio of the crushedrock high-polymer composites with different particle sizes is large, ranging from 0.3 to 0.5 , and the composites have a good water permeability. The void ratio of the crushed-rock high-polymer composites decreases with an increase in the material mixture ratio. This result is mainly due to the fact that when the void ratio of crushed rock is constant, with the increase in material 


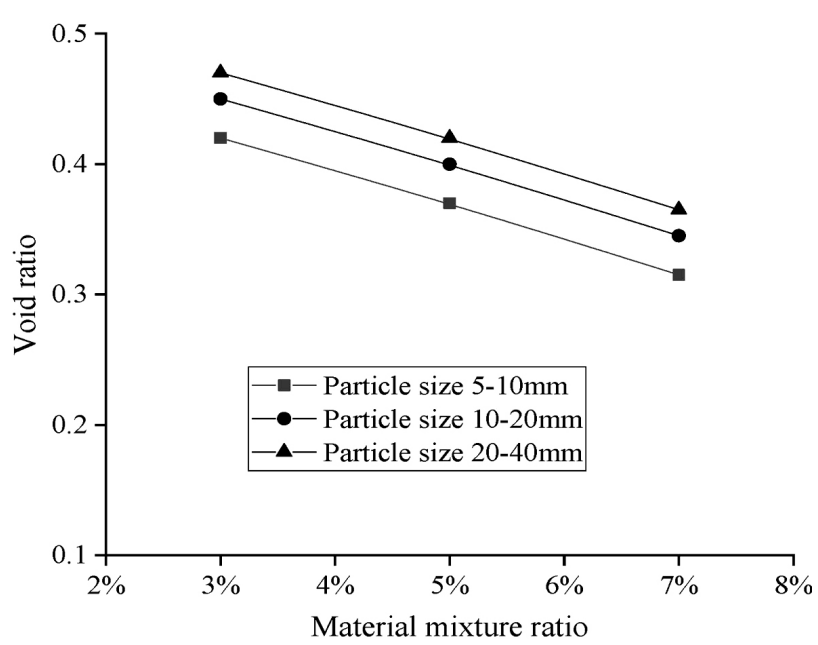

Figure 6: Influence of material mixture ratio on void ratio
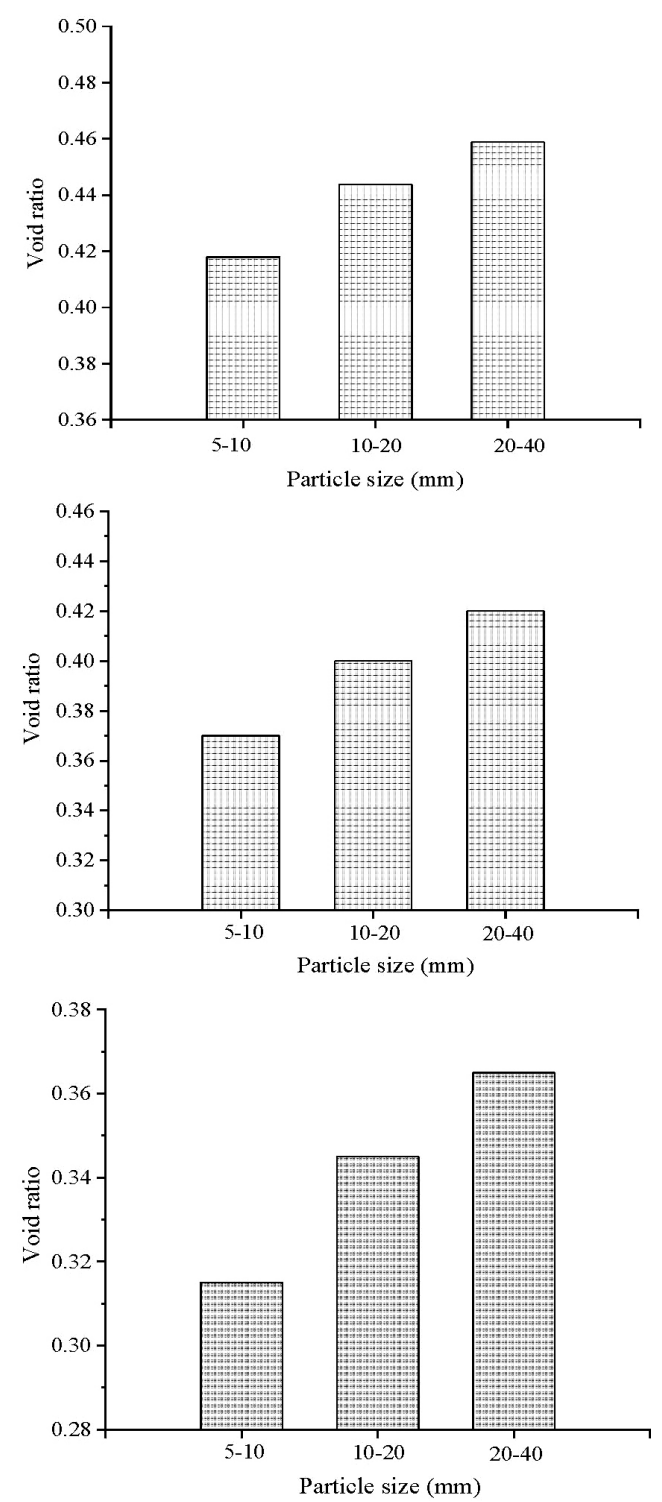

Figure 7: Influence of particle size on the void ratio: a) material mixture ratio of $3 \%, b)$ material mixture ratio of $5 \%, \mathrm{c}$ ) material mixture ratio of $7 \%$ proportion, the coating of the polymer on the aggregate surface thickens, the amount of binder paste at the aggregate connection point increases, and a part of the high polymer is filled in the void of the mixture. Therefore, the void ratio of the crushed-rock high-polymer composites decreases with the increase in the material mixture ratio.

\subsection{Influence of particle size of the crushed rock on the composite void ratio}

The void ratio of the crushed-rock high-polymer composites was not only affected by the material mixture ratio but also by the crushed rock's particle size. The void ratio of the samples with different material mixture ratios and crushed-rock particle sizes was measured. The experimental results are shown in Figure 7.

Figure 7 shows that the void ratio of the composites increases with an increase in the crushed rock's particle size. This result is attributed to the fact that when the particle size of the crushed rock is large, the pore size of the particle itself also increases. Although a decrease in the specific surface area will increase the coating thickness of the high polymer, the overall content of the polymer is extremely low. Thus, the overall void ratio of the material still increases.

\subsection{Influence of the material mixture ratio on the com- posite water permeability}

Firstly, a sample of size of $300 \mathrm{~mm} \times 300 \mathrm{~mm} \times 50$ $\mathrm{mm}$ was poured. Then the permeability coefficient of the composites with different crushed-rock particle sizes and material mixture ratios was measured using a pavement permeameter. The experimental results are shown in Figure 8.

Figure 8 shows that the composite permeability decreases with an increase in the material mixture ratio. However, the decrease is small. When the material mix-

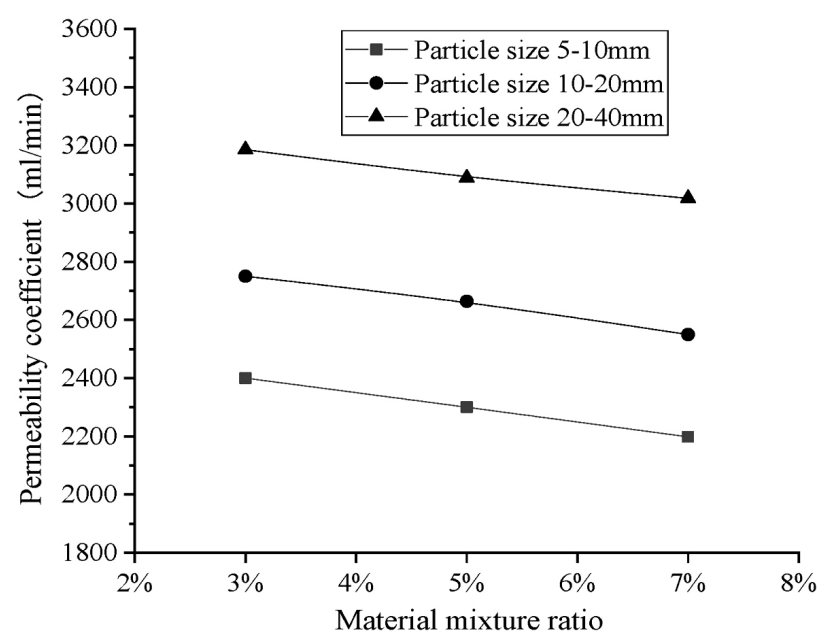

Figure 8: Influence of material mixture ratio on the permeability coefficient 
ture ratio increases from $3 \%$ to $7 \%$, the permeability coefficient decreases by only $8 \%$. The materials with different ratios show good permeability. This finding is mainly due to the fact that the amount of high polymer used in the crushed-rock high-polymer materials is extremely small, and no excess high polymer fills in the void of the mixture at a low material mixture ratio, thereby ensuring the characteristics of the macropore of the mixture. Therefore, as long as the bottom of the composite does not produce high polymer leakage, its water permeability can be satisfied.

\subsection{Scouring resistance of the composites}

To analyse the influence of the crushed rock's particle size and the material mixture ratio on the hydraulic erosion resistance of composites, we carried out scouring tests for the composite materials with the particle size ranges of $1-5 \mathrm{~mm}, 5-10 \mathrm{~mm}$ and $10-20 \mathrm{~mm}$ and material mixture ratios of $3 \%$ and $5 \%$. The flow velocities of the scouring tests were selected as $1 \mathrm{~m} / \mathrm{s}, 3$ $\mathrm{m} / \mathrm{s}$ and $5 \mathrm{~m} / \mathrm{s}$. The experimental results are shown in Table 1 and 2.

Table 1: Statistics of crushed-rock high-polymer composite erosion under water flow (material mixture ratio of $3 \%$ )

\begin{tabular}{|c|c|c|c|}
\hline $\begin{array}{c}\text { Particle size } \\
(\mathrm{mm})\end{array}$ & $\begin{array}{c}\text { Flow velocity } \\
(\mathrm{m} / \mathrm{s})\end{array}$ & $\begin{array}{c}\text { Scouring rate } \\
\left(\mathrm{kg} / \mathrm{m}^{2} \mathrm{~s}\right)\end{array}$ & $\begin{array}{c}\text { Erosion } \\
\text { statistics }\end{array}$ \\
\hline $1-5$ & 1 & 0 & Erosion-free \\
\hline $1-5$ & 3 & 0 & Erosion-free \\
\hline $1-5$ & 5 & 0.01 & Extremely few \\
\hline $5-10$ & 1 & 0 & Erosion-free \\
\hline $5-10$ & 3 & 0 & Erosion-free \\
\hline $5-10$ & 5 & 0 & Erosion-free \\
\hline $10-20$ & 1 & 0 & Erosion-free \\
\hline $10-20$ & 3 & 0 & Erosion-free \\
\hline $10-20$ & 5 & 0 & Erosion-free \\
\hline
\end{tabular}

Table 2: Statistics of crushed-rock high-polymer composite erosion under water flow (material mixture ratio of $5 \%$ )

\begin{tabular}{|c|c|c|c|}
\hline $\begin{array}{c}\text { Particle size } \\
(\mathrm{mm})\end{array}$ & $\begin{array}{c}\text { Flow velocity } \\
(\mathrm{m} / \mathrm{s})\end{array}$ & $\begin{array}{c}\text { Scouring rate } \\
\left(\mathrm{kg} / \mathrm{m}^{2} \mathrm{~s}\right)\end{array}$ & $\begin{array}{c}\text { Erosion } \\
\text { statistics }\end{array}$ \\
\hline $1-5$ & 1 & 0 & Erosion-free \\
\hline $1-5$ & 3 & 0 & Erosion-free \\
\hline $1-5$ & 5 & 0 & Erosion-free \\
\hline $5-10$ & 1 & 0 & Erosion-free \\
\hline $5-10$ & 3 & 0 & Erosion-free \\
\hline $5-10$ & 5 & 0 & Erosion-free \\
\hline $10-20$ & 1 & 0 & Erosion-free \\
\hline $10-20$ & 3 & 0 & Erosion-free \\
\hline $10-20$ & 5 & 0 & Erosion-free \\
\hline
\end{tabular}

Table 1 and $\mathbf{2}$ show that crushed-rock high-polymer composites do not erode under different flow velocities. Especially under conventional flow velocities, i.e., flow velocities of $<3 \mathrm{~m} / \mathrm{s}$, and under the conditions of material mixture ratio and particle size, the composites do not erode. Individual rocks can be peeled off from the edge of the samples with a low material mixture ratio $(3 \%)$ and a small particle size $(1-5 \mathrm{~mm})$ only when the flow velocity increases to $5 \mathrm{~m} / \mathrm{s}$.

The scouring test shows that the crushed-rock highpolymer composite material has excellent scouring resistance, and the formed protective covering can resist high-speed flow scouring. High polymers play a key role in connecting crushed rocks in composite materials, thereby making crushed rock particles unable to rely on their own weight to resist the flow force but form a whole through the polymer cementation from the point stability to block stability to resist high-speed water erosion. Given the porous properties of crushed-rock high-polymer composites, the uplift pressure of the water flow on the materials is also considerably reduced during scouring, which is also conducive to the overall crushed rock particle and material stability. For the samples with a small particle size and $3 \%$ material mixture ratio, only a few particles peel off from the edge of the sample, and the erosion amount and range do not increase after a long water flow time. Therefore, this finding may be closely related to the pouring quality of the sample and the uniformity coefficient of the crushed rock wrapped by the high polymer. With the increase in the particle size of the crushed rock or the material mixture ratio, no erosion occurs in the composites, This result indicates that the crushed rock stability increases with an increase in the particle size or with an increase in the amount of binder paste used, the effect of wrapping particles improves, both of which will improve the resistance of crushedrock high-polymer composites to water erosion.

\section{CONCLUSIONS}

Through a laboratory scouring test system and a pavement permeameter, the water permeability and scouring resistance characteristics of the crushed-rock high-polymer were studied, and the effects of the material mixture ratio, the crushed rock's particle size, the material mixture ratio and the flow velocity were analysed. According to the test results, the main conclusions are as follows:

1) Crushed-rock high-polymer composites have a high void ratio and good water permeability. The void ratio of the composites decreases with an increase in the high polymer and increases with the increase in the particle size.

2) With the increase in the high polymer, the water permeability of the crushed-rock high-polymer composites decreases, but the decrease is small. When the material mixture ratio increases from $3 \%$ to $7 \%$, the water permeability coefficient decreases by only $8 \%$. Composites with different proportions show good permeability.

3) The high polymer in the composite material makes the crushed-rock particles cemented to form a whole from the point stability to the block stability, which can resist the scouring of high-speed flow and has excellent scour resistance. 
4) With the increase in the particle size of the crushed rock, no erosion occurs in the composite, which indicates that the larger the particle size is, the stronger the stability of the composites will be. With the increase in material mixture ratio, no erosion occurs in the composites, thereby indicating that the higher the polymer content is, the better the wrapping effect of the crushed rock particles will be. Increasing the crushed rock particle size and material mixture ratio can improve the scouring resistance of the composites.

\section{Acknowledgments}

The authors are grateful for the financial support from the National Natural Science Foundation of China (No. 51709145), the research project of the Ministry of Housing and Urban-Rural Development (2019-K-131), the Scientific Research Foundation of Nanjing Institute of Technology (YKJ201727).

\section{REFERENCES}

${ }^{1}$ J. Carlos, A. Huerta, H. Oumeraci, Soil stability analysis for waveinduced momentary liquefaction beneath porous bonded revetments, Coastal Engineering, 138 (2018), 22-35, 2018, doi:10.1016/ j.coastaleng.2018.04.003

${ }^{2}$ M. Liu, F. Niu, W. Ma, Experimental investigation on the enhanced cooling performance of a new crushed rock revetment embankment in warm permafrost regions, Applied Thermal Engineering, 120 (2017), 121-129, doi:10.1016/j.applthermaleng.2017.03.118

${ }^{3}$ X. S. He, Y. Pang, Y. H. Lu, Investigation on water purifying revetment technology, Journal of Hydraulic Engineering, 39 (2008) 6, 659-666, doi:10.3321/j.issn:0559-9350.2008.06.004

${ }^{4}$ K. Gunaydin, M. S. Kabdasli, Protection of Shoreline by Using Partial Revetment Structure under Regular and Irregular Waves, Journal of Coastal Research, 22 (2006), 1349-1359, 2006, doi:10.2112/03-0080.1

${ }^{5}$ K. Gunaydin, M. S. Kabdasli, Static stability of submerged partial revetment structures under regular and irregular waves, Ocean Engineering, 30 (2003) 6, 761-777, 2003, doi:10.1016/S00298018(02)00059-8

${ }^{6}$ B. L. Méhauté, Open-Channel Hydraulics/An Introduction to Hydrodynamics and Water Waves, 1976
${ }^{7}$ Y. H. Chen, G. K. Cotton, Design of roadside channels with flexible linings, 1988

${ }^{8}$ P. Northcutt, J. McFalls, Performance testing of erosion control products: what have we learned after five complete evaluation cycles, Proceedings of the International Erosion Control Association Conference, 1998, 199-218

${ }^{9}$ T. Lancaster, A three phase turf reinforcement system a new method for developing geosynthetically reinforced vegetated linings for permanent channel protection, Proceedings of the International Erosion Control Association Conference,1996, 345-354

${ }^{10}$ C. M. Lipscomb, M. Theisen, C. I. Thornton, Performance testing of vegetated systems and engineered vegetated systems, Proceedings of the international erosion control association conference, 2003, 1-13

${ }^{11}$ R. J. Nelson, Research quantifies performance of TRM reinforced vegetation, Proceedings of the Sessions of the Geo-Frontiers 2005 Congress, 2005, 1-11

${ }^{12}$ Y. Li, J. Simunek, Z. Zhang, Water flow and nitrate transport through a lakeshore with different revetment materials, Journal of Hydrology, 520 (2015), 123-133, 2015, doi:10.1016/j.jhydrol.2014.11.045

${ }^{13}$ Y. Pan, L. Li, F. Amini, Influence of Three Levee-Strengthening Systems on Overtopping Hydraulic Parameters and Hydraulic Equivalency Analysis between Steady and Intermittent Overtopping, Journal of Waterway, Port, Coastal, and Ocean Engineering,139 (2012) 4, 256-266, doi:10.1061/(ASCE)WW.1943-5460.0000179

${ }^{14}$ Y. Pan, L. Li, F. Amini, Full-Scale HPTRM-Strengthened Levee Testing under Combined Wave and Surge Overtopping Conditions: Overtopping Hydraulics, Shear Stress, and Erosion Analysis, Journal of Coastal Research, 29 (2012) 1, 182-200, doi:10.2112/ JCOASTRES-D-12-00010.1

${ }^{15}$ L. Li, Y. Pan, F. Amini, Erosion resistance of HPTRM strengthened levee from combined wave and surge overtopping, Geotechnical and Geological Engineering, 32 (2014) 4, 847-857, doi:10.2112/ JCOASTRES-D-12-00010.1

${ }^{16}$ H. Oumeraci, T. Staal, S. Pfortner, Hydraulic performance, wave loading and response of PBA revetments and their foundations, European Journal of Environmental and Civil Engineering, 16 (2012) 8, 953-980, doi:10.1080/19648189.2012.688604

${ }^{17}$ D. Ma, X. X. Miao, G. H. Jiang, An Experimental Investigation of Permeability Measurement of Water Flow in Crushed rock, Transport in Porous Media, 105 (2014) 3, 571-595, doi:10.1007/s11242-0140385-5

${ }^{18}$ J. Qian, Q. Yu, L. Guo, Experimental study on convection characteristics of crushed-rock layer, Canadian Geotechnical Journal, 50 (2013) 8, doi:10.1139/cgj-2011-0201 